\title{
PENGARUH PENERAPAN STRATEGI PEMBELAJARAN INKUIRI TERHADAP KEMAMPUAN BERPIKIR KRITIS DAN KREATIF SISWA SD
}

\author{
Roni Rodiyana ${ }^{1}$ \\ ronirodiyana@yahoo.com \\ Universitas Majalengka
}

\begin{abstract}
ABSTRAK
Penelitian ini dilaksanakan karena kekhawatiran peneliti tentang kualitas pembelajaran guru di kelas yang kurang intensif dalam hal memberikan pelajaran, selain itu untuk memperoleh gambaran pengaruh Strategi Pembelajaran Inkuiri terhadap kemampuan berpikir kritis dan kreatif siswa dalam pembelajaran IPS di Kelas IV Sekolah Dasar. Penelitian ini merupakan kuasi eksperimen dengan menggunakan rancangan nonequivalent group pre-test post-test design. Kelas eksperimen diberi perlakuan pembelajaran menggunakan Strategi Pembelajaran Inkuiri, sedangkan kelas kontrol menggunakan pembelajaran konvensional. Penelitian ini menggunakan sampel Siswa Kelas IV-A dan Siswa Kelas IV-B SDN Cijati Kecamatan Majalengka Kabupaten Majalengka Tahun Akademik 2012/2013. Pemilihan kelas eksperimen yaitu di kelas IV-A sebanyak 31 siswa dan kelas kontrol yaitu di kelas IV-B sebanyak 31 siswa. Sedangkan instrumen penelitian meliputi Lembar Observasi pelaksanaan proses pembelajaran, Tes tulis, serta dokumentasi. Proses pembelajaran dilakukan oleh guru kelas yang sebelumnya sudah diberikan pemahaman tentang Strategi Pembelajaran Inkuiri.

Dari hasil analisis data di kelas eksperimen dan kelas kontrol, dapat disimpulkan kemampuan berpikir kritis dan kreatif siswa di kelas eksperimen sangat baik dibandingkan dengan di kelas kontrol. Dari hasil data statistik Strategi Pembelajaran Inkuiri efesien untuk mengembangkan kemampuan berpikir kritis dan kreatif siswa.

Peneliti memberikan rekomendasi kepada guru agar senantiasa mengembangkan kemampuan berpikir kritis dan kreatif siswa melalui berbagai macam strategi pembelajaran salah satunya menggunakan Strategi Pembelajaran Inkuiri. Dalam penelitian ini penggunaan Strategi Pembelajaran Inkuiri perlu dikembangkan pada materi pembelajaran yang lainnya serta pada aspek perkembangan yang lain selain berpikir kritis dan kreatif siswa. Dalam setiap kegiatan di sekolah, Guru harus memberikan contoh atau teladan bagaimana bersikap dan berpikir kritis serta berpikir kreatif.
\end{abstract}

Kata Kunci: Strategi Pembelajaran Inkuiri, Berpikir Kritis, Berpikir Kreatif

Penulis adalah Dosen Tetap pada Prodi PGSD Fakultas Pendidikan Dasar dan Menengah Universitas Majalengka 


\section{Pendahuluan}

Dunia pendidikan di Indonesia tidak pernah lepas dari berbagai masalah. Bahkan tak jarang setelah satu masalah terpecahkan akan muncul masalah baru. Hal ini berimbas kepada pendidikan dasar yang perlu pembenahan, upaya peningkatan kualitas mutu pendidikan pada jenjang pendidikan dasar perlu dilakukan secara berkelanjutan dan terintegrasi. Masalah yang fundamental adalah kemampuan berpikir siswa, banyak pendidik yang berkeyakinan bahwa pendidikan di masa sekarang mempersempit wawasan siswa, karena tidak membantu para siswanya untuk berpikir secara kritis dan kreatif.

Permasalahan saat ini yang menghambat siswa untuk berpikir kritis dan berpikir kreatif yaitu masih banyak guru yang jarang menggunakan strategi pembelajaran yang sesuai dengan tujuan kurikulum dan lebih sering menggunakan pembelajaran yang sederhana atau konvensional. Permasalahan yang dihadapi bukan saja masalah pada gurunya sendiri tapi juga proses berpikir peserta didik, hal ini harus menjadi tanggung jawab seorang guru bagaimana mengarahkan anak didik supaya bisa berpikir kreatif dan kritis secara efektif.

Menurut Swartz and Perkins dalam Zaleha (2007) beberapa masalah mengenai kesalahan dalam berpikir yang tidak efektif yaitu tergesa-gesa, acak-acakan, tidak fokus, dan sempit. Untuk lebih jelasnya mengenai permasalahan-permasalahan riil yang terjadi di lapangan berdasarkan hasil observasi yaitu:

1. Mata pelajaran IPS cenderung dianggap mata pelajaran yang kurang penting sehingga membosankan, alasannya karena materi pelajarannya bersifat hapalan, sehingga beranggapan bahwa mata pelajaran ini semakin termarjinalkan.

2. Kegiatan proses belajar mengajar selama ini cenderung hanya menekankan hanya pada aspek kognitif saja, sementara aspek afektif dan psikomotornya dianggap sangat sulit untuk diaplikasikan. Selain itu guru atau tenaga pendidik cenderung hanya untuk mencapai target materi kurikulum saja, lebih penting pada penghafalan konsep dari pada pemahaman konsep.

3. Strategi, metode, pendekatan dan model pembelajaran yang digunakan bersifat konvensional.

Sehubungan dengan permasalahanpermasalahan tersebut, maka upaya untuk meningkatan kemampuan berpikir kritis dan kreatif siswa dalam mata pelajaran Ilmu Pengetahuan Sosial merupakan suatu kebutuhan dan keharusan seorang guru dalam mengembangkan potensi berpikir anak didik. Salah satu strategi pembelajaran yang dapat digunakan sebagai solusi untuk meningkatkan kemampuan berpikir kritis dan kreatif siswa yaitu dengan penggunaan strategi pembelajaran inkuiri.

Masalah utama yang perlu dijawab melalui penelitian ini adalah "Apakah Strategi Pembelajaran Inkuiri memberikan pengaruh yang signifikan terhadap kemampuan berpikir kritis dan berpikir kreatif siswa kelas IV Sekolah Dasar?". Kemudian penelitian ini diharapkan dapat memberikan manfaat bagi semua pihak yang berkaitan dengan pendidikan, terutama bagi guru dan siswa yang terlibat langsung dalam proses pembelajaran di kelas, adapun manfaat penelitian ini yaitu :

\section{Manfaat bagi guru}

a. Menambah wawasan guru dalam menggunakan strategi pembelajaran inkuiri dan mampu memahami tahapan, perencanaan, langkahlangkah, keunggulan dan kelemahan strategi pembelajaran inkuiri.

b. Menambah pengetahuan guru dalam menyajikan pembelajaran di lingkungan sekolah yang dapat meningkatkan kemampuan berpikir kritis dan berpikir kreatif siswa dalam 
rangka mengatasi permasalahan pembelajaran yang dihadapi siswa.

2. Manfaat bagi siswa

a. Menambah wawasan siswa mengenai cara belajar yang sesuai dengan kemampuan otak secara alami dengan konsep berpikir kritis dan kreatif.

b. Menambah pengetahuan siswa mengenai cara belajar yang dapat meningkatkan kemampuan berpikir kreatif dan kemampuan berpikir kritis siswa.

c. Menambah pemahaman siswa bahwasannya berpikir kritis dan berpikir kreatif akan mempermudah dalam menyelesaikan permasalahan yang ada di lingkungan sekolah ataupun di lingkungan teman sebaya dan keluarga.

\section{Strategi Pembelajaran Inkuiri}

Menurut Wina (2010: 196) strategi pembelajaran inkuiri adalah rangkaian kegiatan pembelajaran yang menekankan pada proses berpikir secara kritis dan analitis untuk mencari dan menemukan sendiri jawaban dari suatu masalah yang dipertanyakan. Strategi pembelajaran inkuiri pada awalnya banyak diterapkan dalam ilmuilmu alam (natural science). Namun demikian, para ahli pendidikan ilmu sosial mengadopsi strategi inkuiri yang kemudian dinamakan inkuiri sosial. Hal ini didasarkan pada asumsi pentingnya pembelajaran IPS pada masyarakat yang semakin cepat berubah.

Ada beberapa hal yang menjadi ciri utama Strategi Pembelajaran Inkuiri (Wina, 2010: 196), yaitu:

a. Strategi Pembelajaran Inkuiri menekankan pada aktivitas siswa secara maksimal untuk mencari dan menemukan, artinya peserta didik dijadikan subyek belajar.

b. Seluruh aktivitas yang dilakukan siswa diarahkan untuk mencari dan menemukan jawaban sendiri dari suatu yang dipertanyakan. Strategi inkuiri ini menempatkan guru sebagai fasilitator dan motivator, bukan sebagai sumber belajar yang menjelaskan saja.

c. Tujuan dari penggunaan strategi inkuiri adalah mengembangkan kemampuan berpikir secara sistematis, logis dan kritis atau mengembangkan kemampuan intelektual sebagai bagian proses mental.

Langkah-langkah Pelaksanaan Strategi Pembelajaran Inkuiri menurut Wina (2010: 201), adalah sebagai berikut:

a. Orientasi adalah langkah untuk membina suasana atau iklim pembelajaran yang responsif. Pada langkah ini guru mengkondisikan agar siswa siap melaksanakan proses pembelajaran.

b. Merumuskan Masalah

Merumuskan masalah merupakan langkah membawa siswa pada persoalan yang mengandung teka-teki. Persoalan yang disajikan adalah persoalan yang menantang siswa untuk berpikir memecahkan teka-teki.

c. Merumuskan Hipotesis

Hipotesis adalah jawaban sementara dari suatu permasalahan yang sedang dikaji. Sebagai jawaban sementara, hipotesis perlu diuji kebenarannya.

d. Mengumpulkan Data

Mengumpulkan data adalah aktivitas menjaring informasi yang dibutuhkan untuk menguji hipotesis yang diajukan.

e. Menguji Hipotesis

Menguji hipotesis adalah proses menentukan jawaban yang dianggap diterima sesuai dengan data atau informasi yang diperoleh berdasarkan pengumpulan data. Yang terpenting dalam menguji hipotesis adalah mencari tingkat keyakinan siswa atas jawaban yang diberikan.

f. Merumuskan Kesimpulan

Merumuskan kesimpulan adalah proses mendeskripsikan temuan yang diperoleh berdasarkan hasil pengujian hipotesis. 


\section{Berpikir Kritis}

Berpikir kritis menurut Schafersman, S.D. dalam Mustaji (2009) adalah berpikir yang benar dalam rangka mengetahui secara relevan dan reliabel tentang dunia. Berpikir kritis adalah berpikir beralasan, mencerminkan, bertanggungjawab, kemampuan berpikir yang difokuskan pada pengambilan keputusan terhadap apa yang diyakini atau yang harus dilakukan. Berpikir kritis adalah cerdik mengajukan pertanyaan yang sesuai, mengumpulkan informasi yang relevan, mengurutkan informasi secara efisien dan kreatif, menalar secara logis, hingga sampai pada kesimpulan yang reliabel dan terpercaya.

Ciri-ciri orang berpikir kritis menurut Raymon S. Nickerson dalam Kemendiknas (2010: 13) adalah sebagai berikut:

1) Menggunakan bukti yang kuat dan tidak memihak.

2) Dapat mengungkapkan secara ringkas dan masuk akal.

3) Dapat membedakan secara logis antara simpulan yang valid dan tidak valid.

4) Menggunakan penilaian, bila tidak ada bukti yang cukup untuk mendukung sebuah keputusan.

5) Mampu mengantisipasi kemungkinan konsekuensi dari suatu tindakan.

6) Dapat mencari kesamaan dan analogi (kemiripan).

7) Dapat belajar secara mandiri.

8) Menerapkan teknik pemecahan masalah (problem solving).

9) Menyadari fakta bahwa pemahaman seseorang selalu terbatas.

10) Mengakui kekurangan terhadap pendapatnya sendiri.

Selain sejumlah ciri-ciri dalam berpikir kritis, ada beberapa aspek dan indikator menurut Ennis dalam Ishak (2011: 60), yaitu:

1) Memberikan penjelasan sederhana, meliputi memfokuskan pertanyaan; menganalisis argumen; bertanya dan menjawab pertanyaan.

2) Membangun keterampilan dasar, meliputi mempertimbangkan apakah sumber dapat dipercaya atau tidak; mengobservasi dan mempertimbangkan laporan observasi.

3) Menyimpulkan, meliputi mendeduksi dan mempertimbangkan hasil deduksi; menginduksi dan mempertimbangkan hasil induksi; membuat dan menentukan hasil pertimbangan.

4) Memberikan penjelasan lanjut, meliputi mendefinisikan istilah dan mempertimbangkan suatu definisi; mengidentifikasi asumsi-asumsi.

5) Mengatur strategi dan taktik, meliputi menentukan suatu tindakan; berinteraksi dengan orang lain.

\section{Berpikir Kreatif}

Menurut Utami Munandar (2002) kreatif adalah kemampuan untuk membuat kombinasi baru, berdasarkan data, informasi, atau unsur-unsur yang ada. Dalam hal ini, Munandar mengartikan bahwa kreatif sesungguhnya tidak perlu menciptakan halhal yang baru, tetapi merupakan gabungan (kombinasi) dari hal-hal yang sudah ada sebelumnya. Kreativitas (berpikir kreatif atau berpikir divergen) adalah kemampuan berkreasi berdasarkan data atau informasi yang tersedia dalam menemukan banyak kemungkinan jawaban terhadap suatu masalah, dimana penekanannya adalah pada kuantitas, ketepatgunaan, dan keragaman jawaban.

Menurut Utami Munandar (2002: 71) ciri-ciri orang yang berpikir kreatif adalah sebagai berikut:

(1) Rasa ingin tahu yang luas dan mendalam, (2) Sering mengajukan pertanyaan yang baik, (3) Memberikan banyak gagasan dan usulan terhadap suatu masalah, (4) Bebas dalam menyatakan pendapat, (5) Mempunyai rasa keindahan yang mendalam, (6) Menonjol dalam salah satu bidang seni, (7) Mampu melihat 
suatu masalah dari berbagai segi atau sudut pandang, (8) Mempunyai rasa humor yang luas, (9) Mempunyai daya imajinasi, (10) Orisinil dalam ungkapan gagasan dan dalam pemecahan masalah.

Ciri-ciri di atas merupakan skala untuk berpikir kreatif dimana untuk menilai atau mengukur ciri-ciri intelektual umum, ciri-ciri motivasi, dan ciri-ciri kreativitas. Selain berpikir kritis, berpikir kreatif juga sangat baik jika diterapkan dan dibelajarkan kepada anak SD supaya mereka terbiasa dengan pola berpikir seperti itu, dan akan membuat anak berpikir kreatif dalam menghadapi berbagai persoalan yang datang terhadap mereka. Berpikir kreatif identik dengan membuat halhal yang baru dari bahan-bahan yang sudah ada.

\section{Metode Penelitian}

Desain penelitian yang digunakan dalam penelitian ini adalah menggunakan metode eksperimen kuasi. Metode ini digunakan untuk mengetahui peningkatan berpikir kritis dan kreatif siswa sekolah dasar antara yang mendapat pembelajaran dengan strategi pembelajaran inkuiri dengan siswa yang mendapat pembelajaran konvensional.

Penelitian eksperimen kuasi yang akan dilaksanakan yaitu dengan bentuk nonequivalent groups pretest-posttets design yang mengacu pendapat Fraenkel dan Wallen dalam Darmadi (2011: 97). Dimana dilakukan tes awal (pretest) terhadap kedua kelompok tersebut berupa soal tes. Pada kelas eksperimen diberi perlakuan dengan penggunaan strategi pembelajaran inkuiri dan pada kelas kontrol dengan pembelajaran konvensional. Setelah kedua kelompok mendapat perlakuan dalam pembelajaran, maka diakhiri dengan pemberian tes akhir (post test) terhadap kedua kelompok siswa itu berupa soal tes.

Penelitian ini dilakukan di SDN Cijati Kecamatan Majalengka Kulon Kabupaten Majalengka pada bulan Mei Tahun Akademik 2012/2013. Subjek dalam penelitian ini adalah siswa kelas IV SDN Cijati, di mana kelas IV SDN Cijati terdiri dari dua kelas yaitu kelas IV-A dan kelas IVB. Selanjutnya kelas IV-A sebagai kelas eksperimen dan kelas IV-B sebagai kelas kontrolnya, dengan jumlah siswa kelas IV-A dan kelas IV-B sebanyak 31 siswa.

Prosedur dalam penelitian ini yaitu tahap persiapan, tahap pelaksanaan, dan tahap pengolahan dan analisis data. Untuk lebih jelasnya sebagai berikut:

1. Tahap persiapan

pendekatan, strategi, model pembelajaran, metode, dan media pembelajaran yang sedang dilaksanakan pada mata pelajaran IPS Sekolah Dasar.

b. Menentukan permasalahan yang akan diteliti yaitu berupa perbandingan kelas yang didesain dengan menggunakan strategi pembelajaran inkuiri dengan kelas yang tidak didesain dengan menggunakan strategi pembelajaran inkuiri.

c. Hasil dari identifikasi masalah dilanjutkan dengan studi kepustakaan atau sumber rujukan berupa buku atau sumber lain yang membahas tentang strategi pembelajaran inkuiri. Kemudian studi lapangan untuk mengetahui proses pembelajaran yang dilaksanakan oleh guru pada mata pelajaran IPS di Sekolah Dasar.

d. Menentukan subjek penelitian, penelitian ini akan dilaksanakan di kelas IV, yaitu di SDN Cijati kelas IVA dan kelas IV-B, dimana kelas eksperimennya yaitu kelas IV-A dan kelas kontrolnya yaitu di kelas IV-B. Kelompok kelas eksperimen yang menggunakan strategi pembelajaran inkuiri, dan kelompok kelas kontrol yang tidak menggunakan strategi pembelajaran inkuiri.

e. Peneliti memberikan arahan dan pelatihan kepada guru kelas IV di kelas eksperimen tentang pengelolaan 
pembelajaran dengan menggunakan strategi pembelajaran inkuiri.

f. Peneliti bersama guru menyusun instrumen penelitian berupa RPP yang didesain dengan menggunakan strategi pembelajaran inkuiri dan instrumen tes (tes tulis).

g. Pengujian instrumen dengan tujuan agar valid dan dapat dipertanggung jawabkan.

h. Analisis hasil uji validitas dan reliabilitas instrumen.

i. Hasil uji coba instrumen setelah perbaikan kemudian disahkan untuk digunakan dalam proses penelitian.

2. Tahap pelaksanaan

a. Pelaksanaan pretest untuk mengetahui kemampuan awal siswa sebelum ada perlakuan.

b. Pelaksanaan perlakuan oleh guru dengan penggunaan strategi pembelajaran inkuiri dan pembelajaran tanpa penggunaan strategi pembelajaran inkuiri.

c. Observasi kelas tentang pelaksanaan pembelajaran pada kelas eksperimen dan kelas kontrol.

d. Postest untuk mengetahui tingkat prestasi belajar siswa pada kelas eksperimen dan kelas kontrol.

e. Wawancara dengan guru di kelas eksperimen untuk mengetahui pendapatnya mengenai penggunaan strategi pembelajaran inkuiri.

Untuk mendapatkan data yang mendukung dalam penelitian ini digunakan beberapa instrumen penelitian. Instrumen yang digunakan dalam penelitian ini adalah sebagai berikut:

\section{Observasi}

Yaitu dengan cara melihat langsung tempat yang dijadikan objek penelitian sehingga didapat gambaran sesungguhnya secara sistematis. Observasi dilakukan dengan pengamatan, mencatat perilaku dan kegiatan yang terjadi pada keadaan yang sesungguhnya.
2. Tes

Instrumen ini digunakan untuk mengukur peningkatan berpikir kritis dan berpikir kreatif siswa.Data penelitian dikumpulkan dengan cara melaksanakan tes pilihan ganda kemampuan berpikir kritis dan tes tulis esai kemampuan berpikir kreatif siswa pada pembelajaran IPS di kelas IV Sekolah Dasar.

Analisis data dilakukan untuk menjawab rumusan masalah dan pengujian hipotesis. Data yang diperoleh berupa nilai hasil pretes dan postest pada kelas eksperimen dan kelas kontrol akan dianalisis dengan menggunakan perhitungan uji statistik melalui langkah-langkah sebagai berikut:

1. Uji Normalitas Data

Uji normalitas data menurut Furqon (2009)dilakukan untuk mengetahui apakah kedua data penelitian diambil dari populasi yang berdistribusi normal atau tidak. Maka dilakukan uji chi-kuadrat $\left(\mathrm{X}^{2}\right)$ dengan langkah-langkah sebagai berikut:

a. Mencari nilai rata-rata dari data postest pada kelas eksperimen dan kelas kontrol dengan menggunakan rumus sebagai berikut:

$$
\bar{X}=\frac{\sum X}{n}
$$

b. Mencari standar deviasi dengan menggunakan perhitungan langsung memakai kalkulator $f x 3600$.

c. Membuat daftar frekuensi observasi dan mencari standar deviasi frekuensi ekspektasi dengan langkah-langkah sebagai berikut:

1) Mencari banyaknya kelas interval (k) dengan rumus sebagai berikut: $\mathrm{k}=1+3,3, \log \mathrm{n}$

2) Mencari rentang (r) dengan rumus sebagai berikut: $\mathrm{r}=$ skor tertinggi - skor terendah.

3) Mencari panjang kelas interval (p). 
4) Membuat tabel tabulasi sebagai berikut:

\begin{tabular}{|c|c|c|c|}
\hline No. & $\begin{array}{c}\text { Kelas } \\
\text { Interval }\end{array}$ & Tabulasi & Frekuensi \\
\hline & & & \\
& & & \\
\hline \multicolumn{2}{|c|}{$\sum$} & & \\
\hline
\end{tabular}

5) Membuat tabel distribusi frekuensi sebagai berikut:

\begin{tabular}{|c|c|c|c|c|c|c|}
\hline Interval & Oi & bk & $\begin{array}{l}\mathrm{Z}= \\
\frac{b k-\bar{x}}{s d}\end{array}$ & $\mathrm{z}$ & $\boldsymbol{l}$ & $\mathbf{E i}$ \\
\hline 1 & 2 & 3 & 4 & 5 & 6 & 7 \\
\hline & & & & & & \\
\hline$\sum$ & & & & & & \\
\hline
\end{tabular}

d. menghitung nilai $\mathrm{X}^{2}$ (chi-kuadrat) dengan rumus sebagai berikut:

$$
\mathrm{X}^{2}=\sum \frac{(O i-E i)^{2}}{E i}
$$

e. Menentukan derajat kebebasan (db) dengan rumus sebagai berikut: $\mathrm{db}=\mathrm{k}-3$

f. Menentukan nila $X^{2}$ (chi-kuadrat) dari daftar dalam taraf kepercayaan $99 \%$.

g. Menentukan normalitas distribusi dengan ketentuan sebagai berikut:

Jika $X^{2}$ hitung $<X^{2}, 0,99$, maka sampel diambil dari populasi yang berdistribusi normal, dan jika $\mathrm{X}^{2}$ hitung $>X^{2} \quad 0,99$, maka sampel diambil dari populasi yang tidak berdistribusi normal.

2. Uji homogenitas dua varian

Uji ini menurut Furqon (2009) dilakukan dengan maksud untuk mengetahui kesamaan dua variansi yaitu nilai pretest dan postest pada kelas kontrol dan kelas eksperimen. Uji ini dilakukan bila sampel diambil dari populasi yang berdistribusi normal dengan langkahlangkah sebagai berikut: a. Mencari $F$ hitung dengan rumus sebagai berikut:

$\mathrm{F}=\frac{V b}{V k} \mathrm{~V}=s d^{2}$

Keterangan :

$\mathrm{F}=$ nilai homogenitas variansi

$\mathrm{Vb}=$ variansi besar

$\mathrm{Vk}=$ variansi kecil

b. Menentukan derajat kebebasan dengan rumus sebagai berikut:

$\mathrm{db} 1=\mathrm{n} 1-1$

$$
\mathrm{db} 2=\mathrm{n} 2-1
$$

c. Menentukan harga $\mathrm{F}$ dari tabel dengan taraf nyata 0,01 .

d. Menentukan homogentias variansi dengan kriteria sebagai berikut:

Jika F hitung < F tabel, maka kedua variansi tersebut homogen, dan

Jika $\mathrm{F}$ hitung $>\mathrm{F}$ tabel maka kedua variansi tersebut tidak homogen.

3. Uji t

Uji t merupakan cara untuk menguji adanya perbedaan dua rata-rata, dalam hal ini nilai postest pada kelas eksperimen dan kelas kontrol. Melalui uji ini akan diketahui tingkat efektifitas metode proyek terhadap variabel bebas dan variabel terikat. Uji t ini digunakan untuk menjawab hipotesis yang diajukan dalam penelitian ini. Uji $t$ ini dilakukan bila sampel berdistribusi normal dan homogen. Adapun langkah-langkah yang dilakukan dalam uji ini adalah sebagai berikut:

a. Menentukan standar deviasi gabungan dengan rumus sebagai berikut:

$\mathrm{dsg}=\sqrt{\frac{(n 1-1) V 1+(n 2-1) V 2}{n 1+n 2-2}}$

$\mathrm{n} 1=$ jumlah sampel variabel 1

$\mathrm{n} 2=$ jumlah sampel variabel 2

b. Menentukan $\mathrm{t}$ hitung dengan rumus sebagai berikut:

$\mathrm{t}=\frac{\overline{x 1}-\overline{x 2}}{\sqrt[d s g]{\sqrt{\frac{1}{n 1}+\frac{1}{n 2}}}}$

Keterangan :

$\overline{x 1}=$

$\overline{x 2}=$

$d s g=$ 
c. Menentukan derajat kebebasan (db) dengan rumus sebagai berikut: $\mathrm{db}=\mathrm{n} 1+\mathrm{n} 2-2$ keterangan :

$\mathrm{db}=$ derajat kebebasan penyebut

n1 = ukuran sampel yang variansinya besar

$\mathrm{n} 2=$ ukuran sampel yang variansinya kecil

d. Menentukan t tabel dalam taraf kepercayaan $(\alpha)$ ) 0,995\% (berarti pada taraf signifikansi $1 \%$ )

e. Pengujian hipotesis dengan kriteria sebagai berikut:

Jika $t$ hitung $<\mathrm{t}$ tabel maka hipotesis diterima.

Jika $\mathrm{t}$ hitung $>\mathrm{t}$ tabel maka hipotesis ditolak.

\section{Hasil dan Pembahasan}

1. Pengaruh Strategi Pembelajaran Inkuiri terhadap kemampuan berpikir kritis

Berdasarkan hasil perhitungan diperoleh nilai $\mathrm{t}$ hitung sebesar 3,96 dan $\mathrm{t}$ tabel $=2,66$ pada taraf signifikan $1 \%$. Ini berarti nilai $t$ hitung berada diluar ketentuan $-\mathrm{t}$ tabel $<\mathrm{t}$ hitung $<\mathrm{t}$ tabel, maka hal ini menunjukan terdapat perbedaan yang signifikan antara nilai tes akhir (postest) kemampuan berpikir kritis dengan pembelajaran konvensional pada kelas kontrol dan pada kelas eksperimen dengan menggunakan Strategi Pembelajarn Inkuiri atau dengan kata lain hipotesis diterima.

Data penelitian hasilnya signifikan dengan rata-rata skor 8,12 yaitu dimana ratarata pretest kemampuan berpikir kritis siswa SD di kelas kontrol yaitu sebesar 6,61 dan rata-rata postest 7,09 . Kemudian skor ratarata pretest kemampuan berpikir kritis pada kelas eksperimen yaitu sebesar 6,54 dan ratarata postest 8,12 . Hal ini menunjukan bahwa kemampuan berpikir kritis di kelas kontrol dan di kelas eksperimen jauh berbeda. Hasil di kelas kontrol setelah dilakukan postest meningkat namun relatif kecil yaitu sebesar 0,48; sedangkan pada kelas eksperimen hasilnya sangat meningkat yaitu sebesar 1,58. Selanjutnya posttest kemampuan berpikir kritis siswa antara kelompok kelas kontrol dan kelompok kelas eksperimen terdapat selisih rata-rata skor sebesar 1,03.

Hal ini bisa dipahami bahwa dengan Strategi Pembelajaran Inkuiri anak mampu mengembangkan berpikir kritisnya, anak dilatih menjadi seorang analis serta kritis dalam hal bertanya, anak akan berpikir evaluatif sampai ke tingkat yakin atau reflektif. Sesuai pula dengan Ennisdalam Setiawan (2009) mengatakan bahwa berpikir kritis adalah sesungguhnya suatu proses berpikir yang terjadi pada seseorang serta bertujuan untuk membuat keputusankeputusan yang rasional mengenai sesuatu yang dapat ia yakini kebenarannya. Hal ini memberikan gambaran bahwa siswa sekolah dasar sangatlah penting untuk dirangsang dan dipupuk kemampuan berpikir kritisnya dalam membuat keputusan-keputusan yang rasional dan sesuai dengan keyakinannya yang dapat dipertanggungjawabkan oleh dirinya sendiri. Tanpa memberikan stimulus yang baik terhadap siswa sekolah dasar, kemampuan berpikir kritis anak tidak akan berkembang secara optimal.

Berdasarkan uraian diatas dapat disimpulkan bahwa Strategi Pembelajaran Inkuiri dapat diterapkan sebagai salah satu strategi yang dapat membantu kognisi dan mental anak dalam meningkatkan kemampuan berpikir kritis yang dibuktikan dengan hasil observasi dimana anak yang kurang motivasi dalam mengikuti pembelajaran, mereka menjadi antusias, aktif dalam menjawab dan mengemukakan pendapatnya masing-masing serta dapat berpikir secara rasional dan kritis.

2. Pengaruh Strategi Pembelajaran Inkuiriterhadap berpikir kreatif 
Berdasarkan hasil perhitungan diperoleh nilai $\mathrm{t}$ hitung sebesar 4,98 dan $\mathrm{t}$ tabel $=2,66$ pada taraf signifikan $1 \%$. Ini berarti nilai $t$ hitung berada diluar ketentuan $-\mathrm{t}$ tabel $<\mathrm{t}$ hitung $<\mathrm{t}$ tabel, maka hal ini menunjukan terdapat perbedaan yang signifikan antara nilai tes akhir (postest) kemampuan berpikir kreatif dengan pembelajaran konvensional pada kelas kontrol dan pada kelas eksperimen dengan menggunakan Strategi Pembelajaran Inkuiri atau dengan kata lain hipotesis diterima.

Data hasil penelitian signifikan dengan rata-rata skor 8,29 yaitu dimana skor rata-rata pretest kemampuan berpikir kreatif siswa SD di kelas kontrol yaitu sebesar 6,19 dan ratarata postest sebesar 6,96. Kemudian skor rata-rata pretest kemampuan berpikir kreatif pada kelas eksperimen yaitu sebesar 6,48 dan rata-rata postest sebesar 8,29. Hal ini menunjukan bahwa kemampuan berpikir kreatif di kelas kontrol dan di kelas eksperimen jauh berbeda. Hasil posttest kemampuan berpikir kreatif antara kelas kontrol dan kelas eksperimen terdapat selisih rata-rata skor sebesar 1,33. Selanjutnya di kelas kontrol setelah dilakukan postest hasilnya meningkat namun relatif kecil yaitu sebesar 0,77. Sedangkan pada kelas eksperimen hasilnya sangat meningkat yaitu sebesar 1,81. Hal ini berarti pembelajaran yang tidak menggunakan Strategi Pembelajaran Inkuiri yaitu di kelas kontrol kurang meningkatkan kemampuan berpikir kreatif secara signifikan, sedangkan penggunaan Strategi Pembelajaran Inkuiri yaitu di kelas eksperimen dapat meningkatkan kemampuan berpikir kreatif siswa, dimana terdapat selisih skor rata-rata 1,33 antara kelompok kelas kontrol dan kelompok kelas eksperimen.

Hal ini bisa dipahami dengan Strategi Pembelajaran Inkuiri anak mencari alternatif yang berbeda, sesuai pula dengan pendapat Edward de Bono dalam Imam (2008) berpikir kreatif akan menyimpulkan beberapa argumen seseorang dalam menghadapi suatu persoalan atau masalah. Hal ini sangat baik jika diterapkan dan dibelajarkan kepada anak SD supaya mereka terbiasa dengan pola berpikir seperti itu, dan akan membuat anak selalu berpikir kreatif dalam menghadapi berbagai persoalan yang datang terhadap siswa.

Berdasarkan uraian di atas dapat disimpulkan bahwa Strategi Pembelajaran Inkuiri dapat diterapkan sebagai salah satu strategi yang dapat membantu kognisi dan mental anak dalam meningkatkan kemampuan berpikir kreatif yang dibuktikan dengan hasil observasi dimana anak yang kurang motivasi dalam mengikuti pembelajaran, mereka menjadi antusias, aktif dalam menjawab dan mengemukakan pendapatnya masing-masing serta dapat berpikir secara rasional dan dapat mencari berbagai alternatif jawaban dari setiap persoalan yang ada.

\section{Kesimpulan dan Saran}

Berdasarkan penelitian dan pengolahan data, dapat ditarik kesimpulan bahwa strategi pembelajaran inkuiri terhadap kemampuan berpikir kritis dan kreatif siswa memiliki pengaruh yang sangat signifikan dimana dengan strategi pembelajaran inkuiri siswa dituntut untuk berpikir secara mendalam sampai ke tingkat yakin, mampu untuk menghasilkan sejumlah besar ide-ide atau solusi masalah dalam waktu singkat, mampu untuk secara bersamaan mengusulkan berbagai pendekatan untuk masalah tertentu, mampu untuk memproduksi hal baru, ide-ide asli, dan mampu untuk melakukan sistematisasi dan mengatur rincian ide di kepala dan membawanya keluar. Terdapat perbedaan yang signifikan antara kemampuan berpikir kritis dan berpikir kreatif anak yang menggunakan strategi pembelajaran inkuiri pada kelas eksperimen dengan pembelajaran konvensional pada kelas kontrol. Kemampuan berpikir kritis dan kreatif anak yang menggunakan strategi pembelajaran inkuiri mengalami peningkatan yang sangat signifikan dibandingkan dengan menggunakan pembelajaran konvensional. Hal tersebut akan sangat membantu siswa 
dalam beraktivitas serta mencari pengetahuan atau pemahaman untuk memuaskan rasa ingin tahu sehingga siswa akan menjadi pemikir kritis dan kreatif yang mampu memecahkan berbagai masalah.

Untuk para pengguna hasil penelitian, yaitu guru dan peneliti selanjutnya perlu menggunakan strategi pembelajaran inkuiri agar dapat mengembangkan potensi kemampuan berpikir anak, guru harus mampu menempatkan diri sebagai fasilitator dan motivator belajar agar anak bisa mengaktualisasikan dirinya secara optimal, memberikan kesempatan kepada siswa untuk bebas melakukan eksplorasi, memberikan bimbingan, perhatian dan latihan kepada siswa, materi pelajaran hendaklah berupa masalah yang lebih menantang dan memicu terjadinya konflik kognitif serta pertanyaan arahan yang diajukan oleh guru sebaiknya bersifat terbuka supaya dapat melatih siswa dalam berpikir. Selanjutnya untuk pembuat kebijakan, kemampuan berpikir kritis dan kreatif perlu dikembangkan pada anak sekolah dasar, keduanya merupakan bagian yang sangat penting dari perkembangan kognitif anak. Anak sejak usia sekolah dasar perlu dilatih untuk mengungkapkan ide dan gagasan mereka. Karena tuntutan dari globalisasi inilah siswa harus berpikir kritis dan kreatif untuk dapat bersaing, karena pada saat ini manusia sangatlah berkompetitif dalam berjuang mencapai kesuksesan hidup, maka diperlukan pemikiran yang kritis dan kreatif supaya segala hal dapat bernilai tinggi, dimana dengan berpikir kritis dan kreatif seseorang dapat menghasilkan terobosan-terobosan terbaru yang bernilai jual tinggi di masyarakat. Jika siswa tidak mampu berpikir kritis dan kreatif, maka siswa akan tertinggal jauh dan pikirannya tidak akan berkembang. Penulis mengharapkan dari pembuat kebijakan di lingkungan pendidikan ada upaya dan program-program untuk guru dan siswa dalam mengembangkan kemampuan berpikir kritis dan kreatif.

\section{DAFTAR PUSTAKA}

Darmadi, H. (2011). Metode Penelitian Pendidikan. Bandung: Alfabeta.

Furqon. (2009). Statistika Terapan untuk Penelitian. Bandung: Alfabeta.

Imam, S. E. (2008). Teach Your Child How to Think: (Bono, Edward). London: Penguin Books.

Ishak. (2011). Penggunaan Model Pembelajaran Koopertif Tipe Jigsaw dalam Pembelajaran IPS untuk Meningkatkan Pemahaman Konsep dan Keterampilan Berpikir Kritis Siswa Sekolah Dasar. Tesis SPS UPI Bandung: Tidak diterbitkan.

Kemendiknas. (2010). Bahan Belajar Mandiri: Kajian Kritis. Dirjen PMPTP.

Munandar, Utami. (2002). Kreativitas dan Keberbakatan: Strategi Mewujudkan Potensi Kreatif dan Bakat. Jakarta: Gramedia Pustaka Utama.

Mustaji. (2009). "Pengembangan berpikir kritis dan kreatif" dalam Beyer: Critical Thinking. Social Education, 45 (4).

Sanjaya, Wina. (2010). Strategi Pembelajaran Berorientasi Standar Proses Pendidikan. Jakarta: Kencana.

Setiawan, N. et al. (2009). "Critical Thinking (Ennis)". Jurnal Pendidikan. 1, (8), 6380.

Zaleha. (2007). Mengasah Pikiran Kritis dan Kreatif. Bandung: Nuansa. 